\title{
Cryptococcal Choroid Plexitis an Uncommon Fungal Disease. Case Report and Review
}

\author{
Cárdenas Hernández Graciela Agar, Vega Orozco Rosalba, Castro Macias Ivan, Fleury Agnes, \\ Gómez Amador Juan Luis, Soto Hernández. José Luis
}

Can. J. Neurol. Sci. 2009; 36: 117-122

Cryptococcus is the most common fungus that affects the central nervous system, producing diverse clinical manifestations. ${ }^{1,2}$

Before the HIV epidemic, cryptococcosis was an uncommon systemic fungal infection associated with impaired immunity such as haematological malignancies, solid-organ transplantation, chronic use of corticosteroids and other immunosuppressive treatments ${ }^{2}$. The incidence of this infection in immunocompetent patients varied from 0.2 to 0.8 per 100.000 depending on the geographic areas ${ }^{3,4}$. As the HIV epidemic expanded in the 1980, C. neoformans emerged as an important opportunistic infection in the United States, Europe and Australia, occurring in 5-10\% of all AIDS patients ${ }^{4-10}$, and in up to 20 to $30 \%$ in developing countries ${ }^{11-15}$.

The mortality of extrapulmonar cryptococcal infection is $20 \%$ overall despite appropriate antifungal therapy ${ }^{1,2}$. Several epidemiological reports have demonstrated that Cryptococcus is more prevalent in Africa with an average mortality in subSaharan regions over $40 \%,{ }^{11,16-18}$ while in developed countries is around $10 \%$ to $25 \%{ }^{19}$.

In this article we report the case of an immunocompetent woman with cryptococcal infection involving primarily the choroid plexus, emphasizing the role of surgery and biopsy in the diagnosis and medical treatment.

\section{Case Report}

A 39-year-old healthy woman without a previous history of immunosuppresion, lymphoreticular malignancy, corticosteroid use or sarcoidosis, developed daily moderate headache three months before admission. One month later headache increased and was associated with nausea and vomiting and she was admitted to another hospital with papilledema and bilateral paresis of sixth cranial nerve. A head CT scan was normal; on lumbar puncture cerebrospinal fluid (CSF) pressure was 300 $\mathrm{mmH}_{2} \mathrm{O}$, CSF analysis was reported without cells and with normal protein and glucose levels. A diagnosis of idiopathic intracranial hypertension was made and treatment with acetazolamide and furosemide started. She improved and one

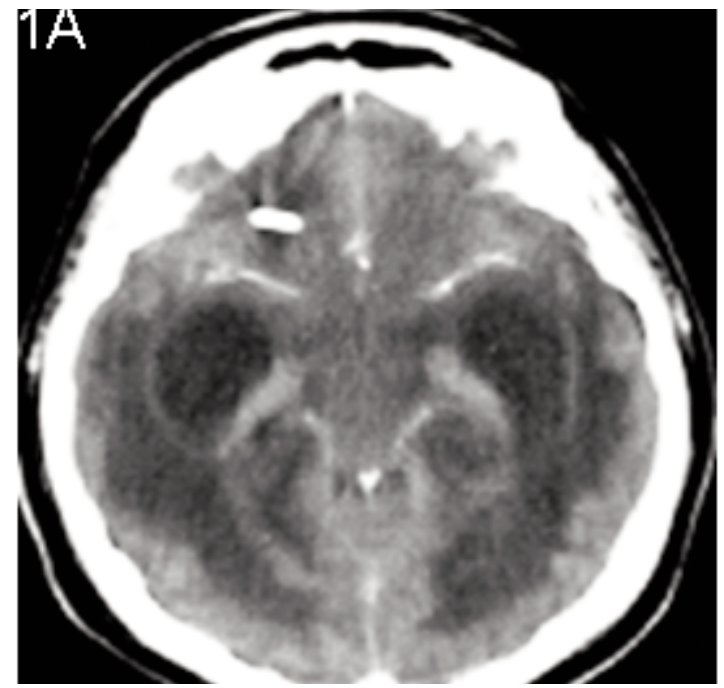

Figure 1A: Contrast-enhanced axial CT scan upon admission shows asymmetric hydrocephalus, lineal and nodular ependymal enhancement and brainstem compression.

month later, headache relapsed with nausea, vomiting, diplopia, and confusion. A right parieto-occipital ventriculoperitoneal shunt (VPS) was placed without improvement. She became somnolent, developed urinary and fecal incontinence and then was transferred to our Institution; upon admission she was found with poor attention, mutism and perseverance, the neurological examination revealed a right central facial palsy, spared brainstem reflexes, hyperreflexia, ataxic gait and bilateral extensor plantar reflexes. Her neurological condition rapidly deteriorated and remained stuporous. The CT scan and MRI showed asymmetric hydrocephalus and ependymal enhancement with nodular areas, temporal horns were dilated producing brainstem compression (Figure 1A, B, C and D). First diagnostic

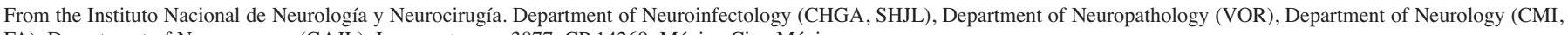
FA), Department of Neurosurgery (GAJL), Insurgentes sur 3877, CP 14269, México City, México.

Received June 25, 2008. Final Revisions Submitted September 3, 2008.

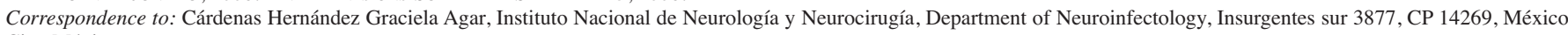
City, México. 


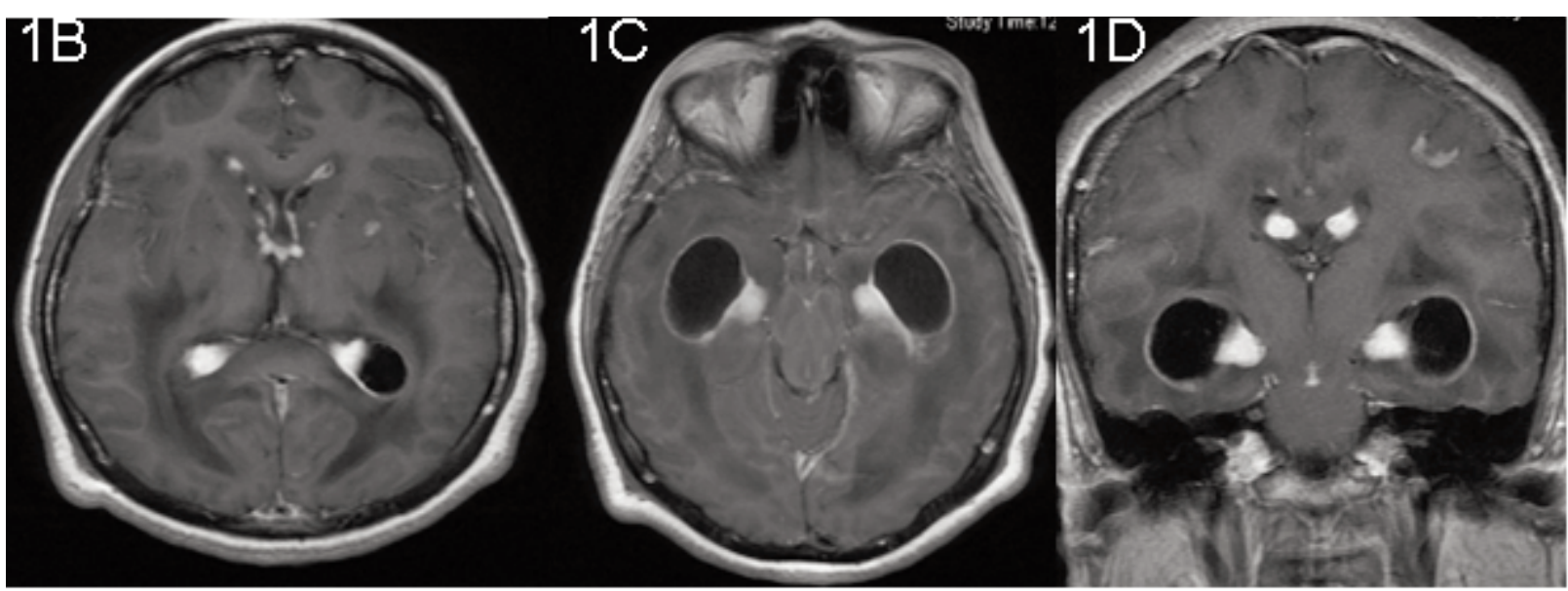

Figure 1B,C,D: Contrast-enhanced axial and coronal T1 weighted imaging upon hospital admission, shows temporal horn dilation, ependyma and choroid plexus enhancement with transependymal migration of CSF.

considerations were diffuse central nervous system (CNS) lymphoma or a chronic infectious process. The HIV serology was negative. Emergency bitemporal craniectomies, VPS and biopsies were performed. After craniectomies a ventricular puncture yielded turbid CSF, cell count was 64 per $\mu \mathrm{L}$ (95\% of lymphocytes and $5 \%$ polymorphonuclears), protein of $769 \mathrm{mg} / \mathrm{dl}$ and glucose of $14 \mathrm{mg} / \mathrm{dl}$. Biopsies of ependyma and choroid plexus revealed a granulomatous inflammatory reaction with encapsulated yeasts. The Periodic acid-Schiff (PAS) and Grocott stain confirmed Cryptococcus species (Figure 2). The cryptococcal antigen latex test was positive. Bacterial, mycobacterial and fungal cultures of CSF remained negative. Polymerase chain reaction (PCR) for Mycobacterium tuberculosis was also negative, and CSF Adenosine-deaminase was undetectable. Corticosteroids and intravenous amphotericin $B$ at $30 \mathrm{mg} /$ day were given; a total dose of $1350 \mathrm{mg}$ was accumulated over 6.5 weeks. Post-operative CT scan showed resolution of hydrocephalus (Figure 3A). Her mental function improved substantially and she was discharged after 56 days in hospital. She continued her treatment with oral itraconazole $400 \mathrm{mg}$ per day long-term. A control MRI after eight months showed reduction of contrast enhancement in the frontal horns of the lateral ventricles while in the temporal horns enhancement of choroid plexus persisted (Figure 3B, C and D).

\section{RESULTS}

A MEDLINE search with key words "cryptococcal brain infections" and "choroid plexitis", retrieved 496 articles. Only 13 were related to primary choroid plexitis and had complete clinical data. The Table summarized the 23 cases described in these articles. There were 7 women and 16 men. Mean age was $36.4 \pm 17$ years, range from 2 to 69 years. Cryptococcus was the etiologic agent in eight and aetiology was not identified in two patients. In six patients there were immunosuppressant factors such as diabetes, pulmonary fibrosis, leukemia, posttransplantation state and HIV in one case. Seven were immunocompetent and in 13 patients immunological status was not available. Of interest, in the seven immunocompetent patients the infectious agents were cryptococcus in five and nocardia in two. Clinical manifestations of choroid plexitis were variable, intracranial hypertension, headache and confusion predominated. Most common imaging findings were abnormal enhancement of choroid plexus and hydrocephalus. The

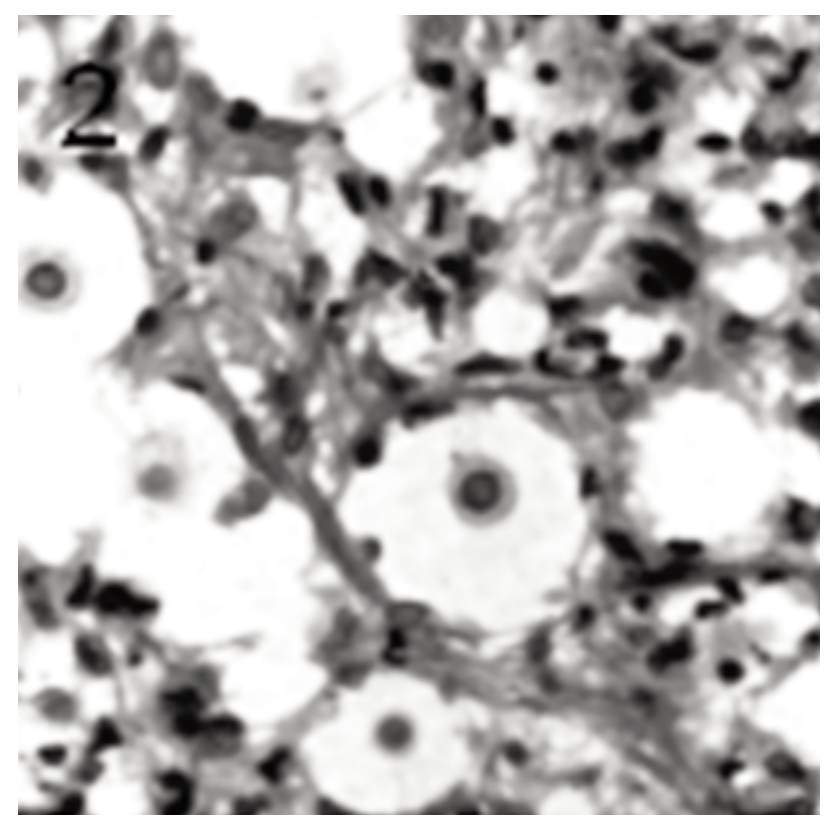

Figure 2: Grocott stain of choroid plexus tissue shows encapsulated yeast of Cryptococcus species. 
Table: Previously reported cases of primary choroid plexitis

\begin{tabular}{|c|c|c|c|c|c|c|c|}
\hline Gender & Age & Clinical manifestations & $\begin{array}{l}\text { CSF white } \\
\text { cells }\end{array}$ & Pathogen isolated & Outcome & $\begin{array}{l}\text { Immunosuppressant } \\
\text { factors }\end{array}$ & Reference \\
\hline Male & 44 & $\begin{array}{l}\text { Intracranial Hypertension and } \\
\text { paraplegia }\end{array}$ & 15 & Cryptococcus & Fatal & None & 1 \\
\hline Female & 45 & Intracranial hypertension & 105 & Cryptococcus & Improvement & None & 63 \\
\hline Female & 37 & Headache and diplopia & 78 & Cryptococcus & Improvement & None & 63 \\
\hline Male & 33 & Headache and fever & 80 & Cryptococcus & Improvement & None & 70 \\
\hline Male & 25 & Headache and fever & 720 & Cryptococcus & Improvement & $\mathrm{Nd}$ & 70 \\
\hline Female & 69 & Headache, vomiting & $\mathrm{Nd}$ & Cryptococcus & Fatal & None & 64 \\
\hline Male & 60 & Dementia and gait disorders & 10 & Cryptococcus & Fatal & $\mathrm{Nd}$ & 64 \\
\hline Male & 48 & Intracranial hypertension & 7 & Cryptococcus & $\mathrm{Nd}$ & $\mathrm{Nd}$ & 45 \\
\hline Male & 34 & Meningitis & 102 & M. tuberculosis & Fatal & $\mathrm{Nd}$ & 65 \\
\hline Male & 55 & Fever, headache and vomiting & 3024 & $\begin{array}{l}\text { None but imaging were } \\
\text { compatible with } M \text {. } \\
\text { tuberculosis }\end{array}$ & Improvement & $\mathrm{Nd}$ & 66 \\
\hline Female & 20 & Meningitis & 252 & M. tuberculosis & Improvement & $\mathrm{Nd}$ & 70 \\
\hline Male & 18 & Headache, fever and vomiting & 320 & M. tuberculosis & Improvement & $\mathrm{Nd}$ & 70 \\
\hline Female & 33 & Stupor and coma & $\mathrm{Nd}$ & N. asteroids & Fatal & $\begin{array}{l}\text { Pulmonary fibrosis and } \\
\text { chronic use of steroids }\end{array}$ & 45 \\
\hline Female & 13 & Headache, fever and vomiting & 1209 & N. asteroids & Improvement & None & 43 \\
\hline Male & 56 & Headache, fever and cough & $\mathrm{Nd}$ & $N$. asteroids & Improvement & None & 71 \\
\hline Male & 19 & Meningitis and intracranial hypertension & 58 & None (Aseptic plexitis?) & Improvement & $\mathrm{Nd}$ & 45 \\
\hline Male & 2 & Meningitis & $\mathrm{Nd}$ & None (Aseptic plexitis?) & $\mathrm{Nd}$ & $\mathrm{Nd}$ & 45 \\
\hline Male & 14 & $\begin{array}{l}\text { Fever post-chemotherapy and } \\
\text { headache }\end{array}$ & $\mathrm{Nd}$ & Stomacoccus mucilaginosus & Improvement & Acute myeloid leukaemia & 67 \\
\hline Male & 46 & $\begin{array}{l}\text { Fever post-chemotherapy and } \\
\text { headache }\end{array}$ & $\mathrm{Nd}$ & Stomacoccus mucilaginosus & Improvement & Acute myeloid leukaemia & 67 \\
\hline Female & 44 & Meningitis & 5 & Streptococci $\alpha$ y $\beta$ & Improvement & Diabetes mellitus & 65 \\
\hline Male & 27 & Headache, fever and vomiting & $3.3 \times 10^{6}$ & Pseudoallescheria boydii & Fatal & Pulmonary fibrosis & 68 \\
\hline Male & 48 & Vertigo and confusion & 12 & Cytomegalovirus & Fatal & $\mathrm{Nd}$ & 69 \\
\hline Male & 33 & Headache, fever and vomiting & 28 & Toxoplasma gondii & Fatal & Epstein Barr virus and HIV & 72 \\
\hline
\end{tabular}

$\mathrm{Nd}=$ No data available

diagnosis was made by biopsy in ten, by CSF study (cultures or immunological test) in nine, by clinical manifestation and MRI in two. Factors related to a poor outcome were delayed diagnosis, a positive HIV status and immunosuppression. Pharmacological treatment was used in 16 patients and both pharmacological and surgical treatment in the rest. The outcome was fatal in eight patients; three of these cases were due to cryptococcal infection.

\section{Discussion}

Cryptococcus serotype and prevalence are quite different between immunocompromised and immunocompetent people. C. neoformans var neoformans (serotypes A and D) is associated with HIV with a prevalence from 2-10\% in Europe and United States, and more than $15 \%$ in Sub-Saharan Africa ${ }^{4,19-22}$, while C. neoformans var gatti (serotypes B and C) has also been isolated in HIV patients, but with a clear predominance for HIV negative persons, as demonstrated in an outbreak on Vancouver Island, Canada in 1999 19,23 . In a Brazilian study C. neoformans var gatti occurred in $7(58.3 \%)$ of the 12 immunocompetent patients and C. neoformans var neoformans in $65(98.5 \%)$ of 66 AIDS patients and in five patients with other immunosuppressive conditions $^{24}$.

As in tuberculosis, the lung is the primary site of infection with granulomatous inflammation ${ }^{25}$, other involved organs are the skin, prostate and eyes. The neurological manifestations are

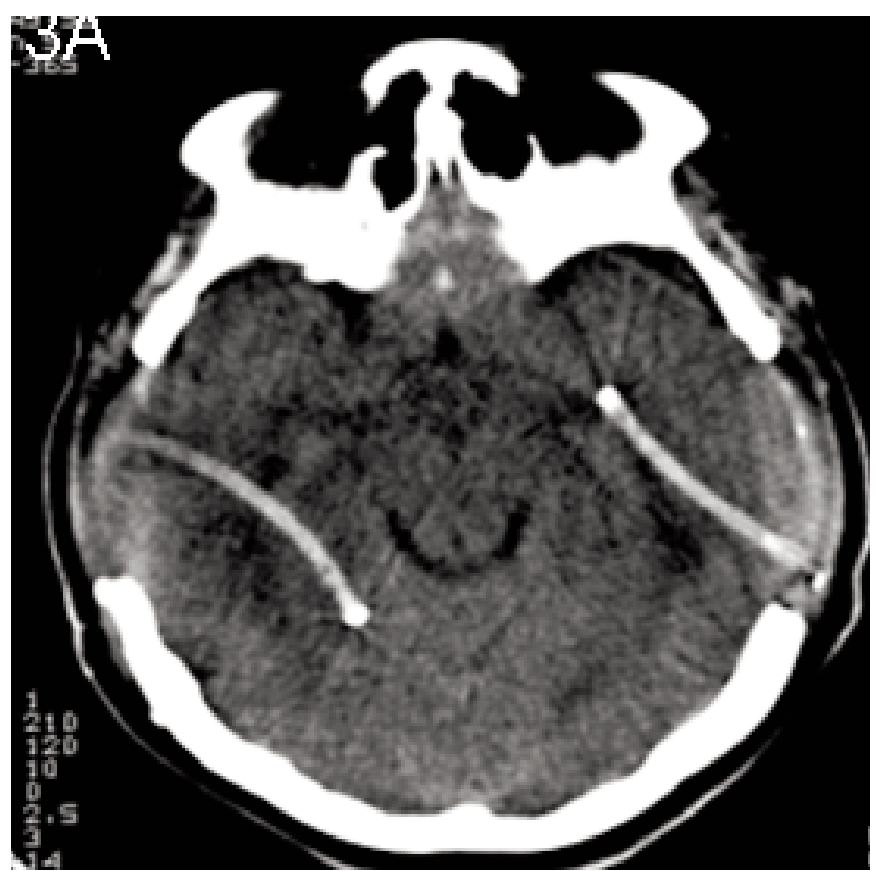

Figure 3A: Non-enhanced axial CT scan one month after surgery shows bilateral craniectomies with ventriculoperitoneal shunts and hydrocephalus resolved. 


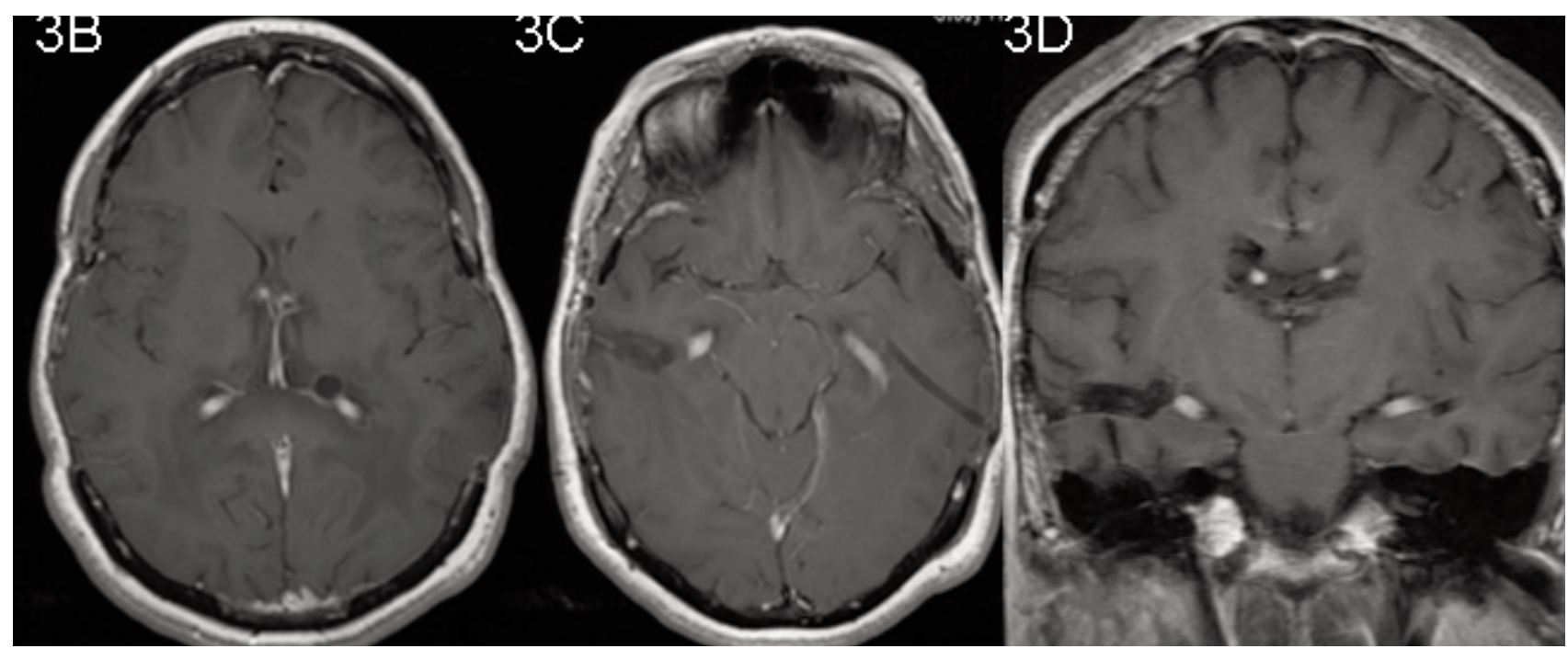

Figure 3B,C,D: Axial and coronal contrast-enhanced T1 weighted control MRI after eight months showed reduction of contrast enhancement in frontal horns of lateral ventricles while in the temporal horns enhancement of choroid plexus persisted.

sub-acute and chronic meningitis or meningoencephalitis ${ }^{25,26}$.

Inflammation predominates in basilar meninges, occasional vasculitis or focal mass lesions are seen. Impaired resorption of CSF produces high CSF pressure and clinical manifestations include headache, papilledema and focal neurological signs, particularly of cranial nerves ${ }^{27}$. Intracranial hypertension (ICH) is multifactorial, based on the liberation of high molecularweight polysaccharides by the active reproduction of the yeast, leading to a higher CSF viscosity and resorption blockage. Also, $\mathrm{D}$-mannitol is released and raises CSF osmolarity ${ }^{28-31}$. These macromolecules cover the brain, the Vichow- Robin spaces and brain parenchyma, reducing the brain "compliance" 32,33 . These factors produce a communicating hydrocephalus, determined by the blockage of the circulation of CSF; however, ventricular size is often normal owing to the loss of the brain "compliance" evolving to a progressive ICH. Our patient had elevated intracranial pressure (ICP) with papilledema and evidence of a focal hydrocephalus by temporal entrapment but in some patients with ICP there is not evidence of obstructive hydrocephalus ${ }^{34}$. In AIDS patients a massive fungal burden leads to an extensive deposition of capsular polysaccharide ${ }^{35}$ that contributes to increase the CSF and interstitial fluid osmolality, promoting fluid accumulation or retention ${ }^{36-38}$.

Diagnosis of cryptococcal choroid plexitis is a challenge for clinicians, due to non specific symptoms or an asymptomatic course, until manifestations of sub-acute or chronic meningitis, $\mathrm{ICH}$ and hydrocephalus appear ${ }^{39}$.

Imaging characteristics of brain cryptococcal infection are protean. The extension of meningeal infection along perivascular spaces may produce small cysts, termed gelatinous pseudocysts in the Virchow-Robin spaces or "soap bubbles", in the basal ganglia, thalamus, substantia nigra and periventricular regions ${ }^{40,41}$. On MRI these structures are typically nonenhancing hypointense lesions on $\mathrm{T} 1$ weighted images and hyperintense on $\mathrm{T} 2$ weighted images. The choroid plexus, spinal cord and nerve roots are occasionally involved ${ }^{6,42}$. Less common manifestations are hydrocephalus and diffuse atrophy. Cryptoccocomas occurred in from $4 \%$ to $11 \%$ of patients with meningitis. The pattern of contrast enhancement in cryptococcal choroid plexitis is non specific and needs to be differentiated of other infectious conditions as: Mycobacterium tuberculosis, Cytomegalovirus, Toxoplasma gondii, Nocardia asteroides and a variety of bacteria, viruses and parasites ${ }^{6,42,43}$, differential diagnosis includes also primary neoplasm (papilloma, carcinoma, ependymoma, hemangioma, lymphoma, meningioma), metastases $^{44,45}$ and several systemic disorders with CNS affection like sarcoidosis ${ }^{46}$, xanthogranulomas ${ }^{47,48}$ and even rheumatoid nodules ${ }^{49}$.

Antifungal drugs constitute the cornerstone of medical treatment of cryptococcal infections in patients with and without immunocompromise, amphotericin B alone, or associated with flucytosine, is effective in most of cases and sterilizes CSF in $60 \%-90 \%$ of patients ${ }^{34,35}$; however, the requirement of intravenous therapy for an extended period of time and the relative toxicity of the regimen, raised alternatives. A frequently used treatment consists of an induction course of amphotericin B $(0.5-1 \mathrm{mg} / \mathrm{kg} / \mathrm{d})$ with flucytosine $(100 \mathrm{mg} / \mathrm{kg} / \mathrm{d})$ for two weeks, followed by a consolidation therapy with fluconazole $(400 \mathrm{mg} / \mathrm{d})$ for an additional eight to ten weeks ${ }^{50-54}$. Our patient received amphotericin B alone at $0.4 \mathrm{mg} / \mathrm{kg} / \mathrm{d}$ for 6.5 weeks as induction and itraconazole $400 \mathrm{mg} / \mathrm{d}$ as consolidation therapy. We did not use flucytosine because is not available in Mexico.

The control of ICH is another important aspect in the management of brain cryptococcosis; usual methods are 
decompression by ventricular drainage, repeated lumbar punctures or medical treatment with acetazolamide or mannitol ${ }^{29,55}$. The CSF shunts have been used to manage ICH in cryptococcal meningitis in patients with and without HIV ${ }^{36,56-60}$, with good long-term outcomes ${ }^{36,60}$. Corticosteroids sharply reduce the release of proinflammatory cytokines by monocytes/macrophages and polymormophonuclear leukocytes $^{61}$ and they may be useful in treating associated vasculitis.

The choroid plexuses are an important target for systemic disorders and a pathway for infectious agents or toxic-metabolic disorders because of richly vascularised epithelium without blood brain barrier ${ }^{43,62}$. The entrapment of the temporal horns of the lateral ventricles, hydrocephalus and intraventricular synechiae due to CSF flow obstruction are secondary to choroidal inflammation ${ }^{38}$. It is still unknown why the infection in some patients persists and remains restricted to the choroid plexus. When lumbar puncture is contraindicated, the realization of CSF shunt and biopsy may be necessary for an accurate diagnosis and proper treatment.

\section{REFERENCES}

1. Kovoor JM, Mahadevan A, Narayan JP, Govindappa SS, Satishchandra P, Taly AV, et al. Cryptococcal Choroid plexitis as a mass lesion: MR imaging and histopathologic correlation. AJNR Am J Neuroradiol. 2002; 23(2):273-6.

2. Perfect JR. Diagnosis and treatment of fungal meningitis. In: Shell WM, Whitley RJ, Durack DT, editors. Infections of the central nervous system. New York: Raven; 1991. p. 729-37.

3. Chayakulkeeree M, Perfect JR. Cryptococcosis. Infect Dis Clin North Am. 2006; 20(3):507-44.

4. Hajjeh RA, Brandt ME, Pinner RW. Emergence of cryptococcal disease: epidemiologic perspectives 100 years after its discovery. Epidemiol Rev. 1995; 17(2):303-20.

5. Selik RM, Karon JM, Ward JW. Effect of the human immunodeficiency virus epidemic on mortality from opportunistic infections in the United States in 1993. J Infect Dis. 1997; 176(3):632-6.

6. Dromer F, Mathoulin S, Dupont B, Laporte A. Epidemiology of cryptococcosis in France: a 9-year survey (1985-1993). French Cryptococcosis Study Group. Clin Infect Dis. 1996; 23(1): 82-90.

7. Mirza SA, Phelan M, Rimland D, Graviss E, Hamill R, Brandt ME, et al. The changing epidemiology of cryptococcosis: an update from population-based active surveillance in 2 large metropolitan areas, 1992-2000. Clin Infect Dis. 2003; 36(6): 789-94.

8. Knight FR, Mackenzie DW, Evans BG, Porter K, Barrett NJ, White GC. Increasing incidence of cryptococcosis in the United Kingdom. J Infect. 1993; 27(2):185-91.

9. Currie BP, Casadevall A. Estimation of the prevalence of cryptococcal infection among patients infected with the human immunodeficiency virus in New York City. Clin Infect Dis. 1994, 19(6): 1029-33.

10. Burckhardt B, Sendi P, Pfluger D, Zimmerli W, Nüesch R, Bucher $\mathrm{HC}$, et al. Rare AIDS-defining diseases in the Swiss HIV cohort study. Eur J Clin Microbiol Infect Dis. 1999; 18(6):399-402.

11. Hakim JG, Gangaidzo IT, Heyderman RS, Mielke J, Mushangi E, Taziwa A, et al. Impact of HIV infection on meningitis in Harare, Zimbabwe: a prospective study of 406 predominantly adult patients. AIDS. 2000, 14(10):1401-7.

12. Kambugu A, Meya DB, Rhein J, O'Brien M, Janoff EN, Ronald $\mathrm{AR}$, et al. Outcomes of cryptococcal meningitis in Uganda before and after the availability of highly active antiretroviral therapy. Clin Infect Dis. 2008; 46(11):1694-701.

13. Bekondi C, Bernede C, Passone N, Minssart P, Kamalo C, Mbolidi
D, et al. Primary and opportunistic pathogens associated with meningitis in adults in Bangui, Central African Republic, in relation to human immunodeficiency virus serostatus. Int J Infect Dis. 2006; 10(5):387-95.

14. Chariyalertsak S, Sirisanthana T, Saengwonloey O, Nelson KE. Clinical presentation and risk behaviors of patients with acquired immunodeficiency syndrome in Thailand, 1994-1998: regional variation and temporal trends. Clin Infect Dis. 2001; 32(6):955-62.

15. Tansuphasawadikul S, Amornkul PN, Tanchanpong C, Limpakarnjanarat K, Kaewkungwal J, Likanonsakul S, et al. Clinical presentation of hospitalized adult patients with HIV infection and AIDS in Bangkok, Thailand. J Acquir Immune Defic Syndr. 1999; 21(4):326-32.

16. Clumeck SB, Sonnet J, Taelman H, Mascart-Lemone F, De Bruyere M, Vande Perre P, et al. Acquired immunodeficiency syndrome in African patients. N Engl J Med. 1984;310(8):492-7.

17. Van de Perre P, Rouvroy D, Lepage P, Bogaerts J, Kestelyn P, Karyihigi $J$, et al. Acquired immunodeficiency syndrome in Rwanda. Lancet. 1984; 2(8394):62-5.

18. Gordon SB, Walsh AL, Chaponda M, Gordon MA, Soko D, Mbwvinji M, et al. Bacterial meningitis in Malawian adults: pneumococcal disease is common, severe and seasonal. Clin Infect Dis. 2000; 31(1):53-7.

19. Perfect JR, Casadevall A. Cryptococcosis. Infect Dis Clin North Am. 2002; 16(4):837-74.

20. Chuck SL, Sande MA. Infections with cryptoccocus neoformans in the adquired immunodeficiency syndrome. N Engl J Med. 1989; 321(12):794-9.

21. Hajjeh RA, Conn LA, Stephens DS, Baughman W, Hamill R, Graviss E, et al. Cryptococcosis: population-based multistate active surveillance and risk factors in human immunodeficiency virus-infected persons. Cryptococcal Active Surveillance Group. J Infect Dis. 1999; 179(2):449-54.

22. Clumeck M, Carael M, Van de Perre P. The Africans AIDS experience in constrast with the rest of the World. Leoung $G$ Mills J, editors: opportunistic infections in patients with the acquired immune deficiency syndrome. New York: Marcel Dekker; 1989. p. 43-56.

23. Kidd SE, Guo H, Barlett KH, Xu J, Kronstad JW. Comparative gene genealogies indicate that two clonal lineages of cryptococcus gatti in British Columbia resemble strains from other geographical areas. Eukaryot Cell. 2005; 4(10):1629-38.

24. Rozenbaum R, Gonçalves AJ, Wanke B, Caiuby MJ, Clemente H, Lazera Mdos S, et al. Cryptococcus neoformans varieties as agents of cryptococcosis in Brazil. Mycopathologia. 1992; 119(3):133-6.

25. Steenbergen JN, Casadevall A. Prevalence of Cryptococcus neoformans var. neoformans (serotype D) and Cryptococcus neoformans var. grubii (serotype A) isolates in New York City. J Clin Microbiol. 2000; 38(5):1974-6.

26. Chen S, Sorrell T, Nimmo G, Seed B, Currie B, Ellis D, et al. Epidemiology and host- and variety-dependent characteristics of infection due to Cryptococcus neoformans in Australia and New Zealand. Australasian Cryptococcal Study Group. Clin Infect Dis. 2000; 31(2):499-508.

27. Rex JH, Larsen RA, Dismukes WE, Cloud GA, Bennett JE. Catastrophic visual loss due to Cryptococcus neoformans meningitis. Medicine (Baltimore). 1993; 72(4):207-24.

28. Calvo A, Hernández P, Spagnuolo E, Johnston E. Surgical treatment of intracranial hypertension in encephalic cryptococcosis. Br J Neurosurg. 2003; 17(5):450-5.

29. Malessa R, Krams M, Hengge U, Weiller C, Reinhardt V, Volbracht $\mathrm{L}$, et al. Elevation of intracranial pressure in acute AIDS-related cryptococcal meningitis. Clin Invest. 1994; 72(12):1020-6.

30. Rosenblum WI. Chronic meningitis and vasculitis in acquired immunodeficiency syndrome. Arch Pathol Lab Med. 1989; 113 (9):966-7.

31. Niehaus W, Flynn T. Regulation of mannitol biosynthesis and degradation by Cryptococcus neoformans. J Bacteriol. 1994; 176 (3):651-5

32. Caldemeyer KS, Mathews VP, Edwars-Brown MK, Smith RR. Central nervous system cryptococcosis: parenchymal calcifications and large gelatinous pseudocyst. AJNR Am J Neuroradiol. 1997; 18(1): $107-9$. 
33. Wong B, Perfect J, Beggs S, Wright KA. Production of the hexitol Dmannitol by Cryptococcus neoformans in vitro and in rabbits with experimental meningitis. Infect Immun. 1990; 58(6):1664-70.

34. Graybill JR, Sobel J, Saag M, van Der Horst C, Powderly W, Cloud $\mathrm{G}$, et al. Diagnosis and management of increased intracranial pressure in patients with AIDS and cryptococcal meningitis. The NIAID Mycoses Study Group and AIDS Cooperative Treatment Groups. Clin Infect Dis. 2000; 30(1):47-54.

35. Lee SC, Casadevall A. Polysaccharide antigen in brain tissue of AIDS patients with cryptococcal meningitis. Clin Infect Dis. 1996; 23(1):194-5.

36. Stevens DA, Denning DW, Shatsky S, Armstrong RW, Adler JD, Lewis BH. Cryptococcal meningitis in the immunocompromised host: intracranial hypertension and other complications. Mycopathologia. 1999; 146(1):1-8.

37. Diamond RD, Benett JE. Prognostic factors in cryptococcal meningitis. A study in 111 cases. Ann Intern Med. 1974; 80(2): 176-81.

38. Donald PR, Schoeman JF, Beyers N, Nel ED, Carlini SM, Olsen $\mathrm{KD}$, et al. Concentrations of interferon gamma, tumor necrosis factor alpha, and interleukin-1 beta in the cerebrospinal fluid of children treated for tuberculous meningitis. Clin Infect Dis. 1995; 21(4):924-9.

39. Netsky MG, Shuangshoti S. The choroid plexus in health and disease. Charlottesville, Va: University of Virginia Press; 1975. p. 249-64.

40. Harris DE, Enterline DS. Neuroimaging of AIDS. I. Fungal infections of the central nervous system. Neuroimaging Clin $\mathrm{N}$ Am. 1997; 7(2):187-98.

41. Tien RD, Chu PK, Hesselink JR, Duberg A, Wiley C. Intracranial cryptococcosis in immunocompromised patients: CT and MR findings in 29 cases. AJNR Am J Neuroradiol. 1991; 12(2):2839.

42. Everett BA, Kusske JA, Rush JL, Pribram HW. Cryptococcal infection of the central nervous system. Surg Neurol. 1978; 9(3):157-63

43. Wells RG, Sty JR. Nocardia Choroid plexitis: CT and MR findings. J Comput Assist Tomogr. 1994; 18(3):484-7.

44. Grossman RI, Yousem DM. Infectious and noninfectious inflammatory diseases of the brain (Choroid plexitis). Neuroradiology: The Requisistes. New York, New York, USA: Mosby. 2003:286-7.

45. Mathews VP, Smith RR. Choroid plexus infections: neuroimaging appearances of four cases. AJNR Am J Neuroradiol. 1992:13(1):374-8

46. Strefling AM, Summerville JW, Urich H. Involvement of the choroid plexuses in neurosarcoidosis. Acta Neuropathol. 1987; 74(4):402-4.

47. Pear BL. Xanthogranuloma of the choroid plexus. AJR Am J Roentgenol. 1984; 143(2):401-2.

48. Hinshaw DB Jr, Fahmy JL, Peckham N, Thompson JR, Hasso AN, Holshouser B, et al. The bright choroid plexus on MR: CT and pathologic correlation. AJNR Am J Neuroradiol. 1988; 9(3):4836

49. Kim RC, Collins GH, Parisi JE. Rheumatoid nodule formation in the choroid plexus. Report of a second case. Arch Pathol Lab Med. 1982; 106(2):83-4.

50. Bennett JE, Dismukes W, Duma RJ, Medoff G, Sande MA, Gallis $\mathrm{H}$, et al. A comparison of amphotericin $\mathrm{B}$ alone and combined with flucytosine in the treatment of cryptococcal meningitis. $\mathrm{N}$ Engl J Med. 1979; 301(3):126-31.

51. Dismukes WE, Cloud G, Gallis HA, Kerkering TM, Medoff G, Craven PC, et al. Treatment of cryptococcal meningitis with combination amphotericin B and flucytosine for four as compared with six weeks. N Engl J Med. 1987; 317(6):334-41.

52. van der Horst C, Saag MS, Cloud GA, Hamill RJ, Graybill JR, Sobel JD, et al. Treatment of cryptococcal meningitis associated with the acquired immunodeficiency syndrome. National Institute of Allergy and Infectious Diseases Mycoses Study Group and AIDS Clinical Trials Group. N Engl J Med. 1997; 337(1):15-21.
53. Saag MS, Graybill RJ, Larsen RA, Pappas PG, Perfect JR, Powderly WG, et al. Practice guidelines for the management of cryptococcal disease. Infectious Diseases Society of America. Clin Infect Dis. 2000; 30(4):710-8.

54. Pukkila -Worley R, Mylonakis E. Epidemiology and management of cryptococcal meningitis: developments and challenges. Expert Opin Pharmacother. 2008; 9(4):551-60.

55. Sharkey PK, Graybill JR. Chronic meningitis. In: Emergent and urgent neurology. Philadelphia: Lippincott, 1992. p. 183.

56. Bach MC, Tally PW, Godofsky EW. Use of cerebrospinal fluid shunts in patients having acquired immunodeficiency syndrome with cryptococcal meningitis and uncontrollable intracranial hypertension. Neurosurgery. 1997; 41(6):1280-2.

57. Mylonakis E, Merriman NA, Rich JD, Flanigan TP, Walters BC, Tashima KT, et al. Use of cerebrospinal fluid shunt for the management of elevated intracranial pressure in a patients with active AIDS-related cryptococcal meningitis. Diagn Microbiol Infect Dis. 1999; 34(2):111-4.

58. Denning DW, Armstrong RW, Lewis BH, Stevens DA. Elevated cerebral spinal fluid pressures in patients with cryptococcal meningitis and acquired immunodeficiency syndrome. Am J Med. 1991; 91(3):267-72.

59. Woodworth GF, Mc Girt MJ, Williams MA, Rigamonti D. The use of ventriculoperitoneal shunts for uncontrollable intracranial hypertension without ventriculomegally secondary to HIVassociated cryptococcal meningitis. Surg Neurol. 2005; 63(6):529-31.

60. Liliang PC, Liang CL, Chang WN, Chen HJ, Su TM, Lu K, et al. Shunt surgery for hydrocephalus complicating cryptococcal meningitis in human immunodeficiency virus-negative patients. Clin Infect Dis. 2003; 37(5):673-8.

61. Lebel MH, Freij BJ, Syrogiannopoulos GA, Chrane DF, Hoyt MJ, Stewart SM, et al. Dexamethasone therapy for bacterial meningitis. Results of two double-blind, placebo-controlled trials. N Engl J Med. 1988; 319(15):964-71.

62. Levine S. Choroid plexus: target for systemic disease and pathway to the brain. Lab Invest. 1987; 56(3):231-3.

63. Patronas NJ, Makariou EV. MRI of choroidal plexus involvement in intracranial cryptococcosis. J Comput Assist Tomogr. 1993; 17(4):547-50.

64. Penar PL, Kim J, Chyatte D, Sabshin JK. Intraventricular cryptococcal granuloma. Report of two cases. J Neurosurg. 1988, 68(1):145-8.

65. Tsugane R, Shimoda M, Yamaguchi T, Yamamoto I, Sato O. Entrapment of temporal horn: a form of focal noncommunicating hydrocephalus caused by intraventricular block of cerebrospinal fluid flow- report of two cases. Neurol Med Chir (Tokyo). 1992; 32(4):210-4

66. Okuda S, Murakami N, Ito E, Hashizume Y. A case of tuberculous meningitis with abnormal contrast enhancement of choroid plexus on CT and MRI. Rinsho Shinkeigaku. 1993; 33(10):10903 .

67. Guermazi A, Miaux Y, Laval-Jeantet M. Imaging of choroid plexus infection by Stomatococcis mucilaginosus in neutropenic patients. AJNR Am J Neuroradiol. 1995; 16(6):1331-4.

68. Albernaz V, Huston B, Castillo M, Mukherji S, Bouldin TW. Pseudoallescheria boydii infection of the brain: imaging with pathologic confirmation. AJNR Am J Neuroradiol. 1996; 17(3):589-92.

69. Guermazi A, Miaux Y, Zagdanski AM, Laval-Jeantet M. Choroid plexitis caused by cytomegalovirus in a patient with AIDS. AJNR Am J Neuroradiol. 1996; 17(7):1398-9.

70. Cho IC, Chang KH, Kim YH, Kim SH, Yu IK, Han MH. MRI features of choroid plexitis. Neuroradiology. 1998; 40(5):303-7.

71. Mogilner A, Jallo GI, Zagzag D, Kelly PJ. Nocardia abscess of the choroid plexus: clinical and pathological case report. Neurosurgery. 1998; 43(4):949-52.

72. de Silva T, Raychaudhuri M, Poulton M, Achar A, Hampton T. Ventriculitis and hydrocephalus: an unusual presentation of toxoplasmosis in adult with human immunodeficiency virus. J Neurol Neurosurg Psychiatry. 2005; 76(8):1074. 